\title{
INVESTIGATING OZONE AMBIENT LEVELS: CASE STUDY OF THE FAHAHEEL URBAN AREA, STATE OF KUWAIT
}

\author{
MASUMAH AL-QASSIMI \& SULTAN MAJED AL-SALEM \\ Environment \& Life Sciences Research Centre, Kuwait Institute for Scientific Research, Kuwait
}

\begin{abstract}
Continuously monitored ambient concentrations of ozone $\left(\mathrm{O}_{3}\right)$, nitrogen monoxide $(\mathrm{NO})$, nitrogen dioxide $\left(\mathrm{NO}_{2}\right)$, and nitrogen oxides (NOx) for the years 2004-2005 and 2014-2015 are used to understand the relationships and photochemical rections between ozone $\left(\mathrm{O}_{3}\right)$ and nitrogen oxides $\left(\mathrm{NO}=\mathrm{NO}+\mathrm{NO}_{2}\right)$ in one of Kuwait's major urban areas (Fahaheel). The objective of the study is to investigate the fate of $\mathrm{O}_{3}$ as a secondary pollutant and to determine the chemical coupling and mixing ratio of $\mathrm{NO}_{2}$ to $\mathrm{O}_{3}$. The variation of total atmopsheric oxides $\left(\mathrm{Ox}=\mathrm{O}_{3}+\mathrm{NO}_{2}\right)$ concentrations with $\mathrm{NO}_{2}$ is also assessed to gain an insight into the atmospheric sources of $\mathrm{Ox}$. In addition, the diurnal variations of $\mathrm{NO}, \mathrm{NO}_{2}, \mathrm{NO}_{x}, \mathrm{O}_{3}$, and $\mathrm{Ox}$ along with variation of regional and local $\mathrm{Ox}$ are examined. The daytime and night-time relationships between $\mathrm{O}_{3}$ and $\mathrm{NO}_{x}$ and the ozone weekend effect in Fahaheel area are also reported in this communication. This study creates a historical baseline for urban areas subjected to heavy industrial emissions that can significantly improve our understanding of the impacts of future changes in $\mathrm{O}_{3}$ concentrations.
\end{abstract}

Keywords: precursors, volatile, pollution, air quality, ozone $\left(\mathrm{O}_{3}\right)$.

\section{INTRODUCTION}

Ozone is a secondary airborne pollutant formed by complex photochemical reactions in air containing nitrogen oxides $\left(\mathrm{NO}_{\mathrm{X}} \approx \mathrm{NO}+\mathrm{NO}_{2}\right)$ and a wide range of volatile organic compounds (VOCs) under the influence of sunlight [1]. Complex nonlinear photochemistry is known to drive the relationships between $\mathrm{O}_{3}, \mathrm{NO}_{\mathrm{X}}$ and VOCs. With increasing concentrations of VOCs, $\mathrm{O}_{3}$ formation tends to increase proportionately. On the other hand, the increase in $\mathrm{NO}_{\mathrm{X}}$ levels results in variations in $\mathrm{O}_{3}$ depending on the dominance of VOCs and $\mathrm{NO}_{\mathrm{X}}$ [2]. Additionally, the response to $\mathrm{NO}_{\mathrm{X}}$ emissions decline is highly nonlinear. Reduction in $\mathrm{NO}_{2}$ levels is always accompanied by an increase in $\mathrm{O}_{3}$ levels [3]. VOCs generated from various human activities are also in need of close monitoring namely from industrial related sources.

In some areas, there exists a trend towards higher levels of $\mathrm{O}_{3}$ concentration on weekends. This is despite low weekend VOCs and $\mathrm{NO}_{\mathrm{X}}$ emissions [4]. This phenomenon is known as the ozone weekend effect and was first reported back in the 1970s in the United States of America (USA) [5]. This effect was also assessed in various parts of the USA and the world namely the State of California and North-Eastern Iberian Peninsula [6]-[7]. Past efforts have also been reported in technical literature covering other parts of the world namely the Arabian Gulf region, Indian Peninsula, Southeast Asia and North America [4], [8]-[13]. Literature on the Middle East (ME) region's air quality status is very scarce and outdated. There is also a shortage of such in-depth analysis of $\mathrm{O}_{3}$ and its precursors in the State of Kuwait, where primary and secondary airborne pollutants are typically associated with the oil and gas industry; unsanitary waste management and unregulated industrial activities. The aim of this study is to investigate the fate of $\mathrm{O}_{3}$ as a secondary pollutant by evaluating the photochemical reactions in one of Kuwait's major urban areas (Fahaheel). 
The study also reports on the daytime and night-time relationships between $\mathrm{O}_{3}$ and $\mathrm{NO}_{\mathrm{X}}$; and investigates the $\mathrm{O}_{3}$ weekend effect in Fahaheel area.

\section{MATERIALS AND METHODOLOGY}

\subsection{Study area}

The Fahaheel urban area $\left(29^{\circ} 05^{\prime} 00^{\prime \prime} \mathrm{N}\right.$ lat. and $48^{\circ} 07^{\prime} 36^{\prime \prime} \mathrm{E}$ long.) is one of five major cities in the State of Kuwait under Al-Ahmadi Governorate. The city is associated with downstream and petrochemical industries supporting the oil-based economy of Kuwait. It is characterised by a typical arid climate with harsh summers. During the summer seasons, ambient temperatures typically exceed $55^{\circ} \mathrm{C}$ in the months June to September. About 100,000 residents are reported to reside in the area which is also adjacent to the state's largest oil refinery (Mina Al-Ahmadi, MAA). All refineries, including MAA comprising Kuwait's three refinery belt alongside Mina Abdullah (MAB) and Shuibah (SHU), are located on the southern side of the main shopping area of Fahaheel (downtown) [14]. On the southern side of the area there are also petrochemical industries and other small private (cottage) industries. Readers are referred to Al-Salem and Khan [14] for a satellite image depicting main routes for commuting and industrial sites around Fahaheel.

\subsection{Data sourcing, analysis and processing}

Continuously monitored air quality data for the years 2004-2005 and 2014-2015 was acquired from the Fahaheel monitoring station (located $15 \mathrm{~m}$ above ground level) by the Air Pollution Monitoring Division, Environment Public Authority, Kuwait (EPA). The ambient air samples were taken from a stationary probe (Group Tek. Model, 3-5 m, stationary photolytic converter, Environment SA and Thermo Models) located at the top of the Fahaheel polyclinic. The samples were examined using various primary pollutant and secondary precursor analysers (Whatman 41, Air sample Grasbey-Anderson Ltd., $1 \%$ tolerance, weather station), all linked to EnviDAS software's central online data acquisition system. Continuous hourly averages of pollutant concentrations namely $\mathrm{O}_{3}$ (ppb), $\mathrm{NO}(\mathrm{ppb}), \mathrm{NO}_{2}(\mathrm{ppb})$, and $\mathrm{NO}_{\mathrm{X}}(\mathrm{ppb})$ were collected in addition to the metrological parameters of ambient temperature $\left({ }^{\circ} \mathrm{C}\right)$, relative humidity $(\mathrm{RH}, \%)$, wind speed $\left(\mathrm{WS}, \mathrm{ms}^{-1}\right)$ and wind direction $\left(\mathrm{WD},{ }^{\circ}\right) . \mathrm{O}_{3}$ is often depleted locally by atmospheric titration in high $\mathrm{NO}_{\mathrm{X}}$ emission regions. $\mathrm{O}_{\mathrm{X}}$ is consequently a more stable entity to study as it shows the potential for renewed production of $\mathrm{O}_{3}$ [15]. Therefore, work on nitrogen-based pollutants included the Ox filtration procedure where points below its line have been discarded due to photo-oxidation reactions, particulate accumulation, choking or $\mathrm{OH}^{-}$ion presence malfunctioning of the instruments. The procedure has been established previously by other authors and illustrated as follows [2], [13]-[14], [16]:

$$
\mathrm{O}_{x}[\mathrm{ppb}]=\mathrm{O}_{3}+\mathrm{NO}_{2} \text {, }
$$

where, $\mathrm{Ox}$ is the total oxide concentration in the ambient atmosphere (ppb). It is well established that the reactions shown below generally dominate the interconversion of $\mathrm{O}_{3}$, $\mathrm{NO}$ and $\mathrm{NO}_{2}$ under atmospheric conditions [1]:

$$
\begin{gathered}
\mathrm{NO}_{2}+h v(\lambda<398 \mathrm{~mm}) \rightarrow \mathrm{NO}+\mathrm{O} \\
\mathrm{O}+\mathrm{O}_{2}+\mathrm{M}\left(\mathrm{N}_{2}, \mathrm{O}_{2}\right) \rightarrow \mathrm{O}_{3}+\mathrm{M}
\end{gathered}
$$




$$
\begin{gathered}
\mathrm{NO}+\mathrm{O}_{3} \stackrel{\mathrm{K}_{3}}{\longrightarrow} \mathrm{NO}_{2}+\mathrm{O}_{2} \\
\mathrm{NO}_{2}+\mathrm{O}_{2} \stackrel{\mathrm{J} 4}{\longrightarrow} \mathrm{NO}+\mathrm{O}_{3} \\
\frac{[\mathrm{NO}] \cdot\left[\mathrm{O}_{3}\right]}{\left[\mathrm{NO}_{2}\right]}=\frac{J_{4}}{k_{3}}
\end{gathered}
$$

where, hv is the sunlight (solar) intensity; $\mathrm{k}_{3}$ is the rate coefficient for the reaction of NO with $\mathrm{O}_{3}$ in eqn (4); and $\mathrm{J}_{4}$ is the rate of $\mathrm{NO}_{2}$ photolysis reaction in eqn (5) at equilibrium [17]. The reactions in eqns (4) and (5) characterise a closed system in which components of $\mathrm{NO}_{\mathrm{X}}\left(\mathrm{NO}+\mathrm{NO}_{2}\right)$ and oxidant $\mathrm{O}_{\mathrm{X}}\left(\mathrm{O}_{3}+\mathrm{NO}_{2}\right)$ relate separately but leave unchanged a total mixing ratio of both $\mathrm{NO}_{\mathrm{X}}$ and $\mathrm{O}_{\mathrm{X}}$ [18]. Over the course of daytime hours, $\mathrm{NO}, \mathrm{NO}_{2}$, and $\mathrm{O}_{3}$ are typically balanced on a time scale of a few minutes called the photo-stationary state. In this study, determining the $\mathrm{J}$ parameter and the $\mathrm{NO}_{2}$ and $\mathrm{O}_{3}$ mixing ratio assisted in investigating the photochemical reactions (photolysis) of the pollutants. It also aided in understating the fate of the pollutants in the ambient and their interaction with each other. Diurnal variation of $\mathrm{NO}, \mathrm{NO}_{2}, \mathrm{NO}_{\mathrm{X}}, \mathrm{O}_{3}$, and $\mathrm{O}_{\mathrm{x}}$ along with variation of seasonal regional and local Ox were also examined in the study.

\section{RESULTS AND DISCUSSION}

\subsection{Ozone and nitrogen oxide(s) diurnal variation and patterns}

The $\mathrm{O}_{3}, \mathrm{NO}, \mathrm{NO}_{2}$ and $\mathrm{NO}_{\mathrm{X}}$ diurnal variation plots of hourly averages for the years 2004-2005 and 2014-2015 are shown in part (Fig. 1). The daily average maximum level of $\mathrm{O}_{3}$ reached $69 \mathrm{ppb}$ during the years 2004-2005 compared to $47 \mathrm{ppb}$ in 2014-2015. The diurnal cycle of $\mathrm{O}_{3}$ concentrations shows high levels with altering morning and late-night concentrations. The lowest concentrations were found at around 5:00 to 8:00 in the early morning hours. The concentration of $\mathrm{O}_{3}$ started to rise rapidly afterwards, coinciding with the increase in solar radiation until it peaked at around 13:00 to 16:00 during the day. Subsequently, it declined rapidly from daytime to evening (18:00) after reaching its maximum value and continued to decline gradually due to the lack of solar radiation. The same $\mathrm{O}_{3}$ daily variability was also observed in past research [16], [19]-[20]. This could be attributed to the photochemical reaction of $\mathrm{O}_{3}$ precursors (e.g. VOCs) with natural ambient air and $\mathrm{NO}_{\mathrm{X}}$ long-range transport [21]. It is well established that the inversion layer, solar intensity, wind patterns and sources of emissions have a significant influence on the daily variability of any pollutant [2], [17]. As seen in previous research these factors may also added to the $\mathrm{O}_{3}$ background levels in the study area [14].

The diurnal variation plots of $\mathrm{NO}_{2}$ established in Figure 1 show two daily peaks during morning and evening periods. The peak values of $\mathrm{NO}$ and $\mathrm{NO}_{2}$ occurred at the same time during morning hours (e.g. 6:00 to 8:00). This coincided with the school rush hour vehicle emissions. The evening peaks occurred between 19:00 to 21:00 in 2004-2005 and in 2014-2015. The evening peaks corresponded to typical urban activities of Fahaheel area (e.g. traffic, shops and markets opening, restaurants, etc). $\mathrm{NO}$ oxidised to $\mathrm{NO}_{2}$ as morning progresses until it reached maximum values in evening times. $\mathrm{NO}_{2}$ hourly average concentrations exceeded NO concentrations, showing higher level of environmental oxidation in the area. The rush hours and increased volumes in traffic during morning times and evening periods coincided with the higher $\mathrm{NO}_{\mathrm{X}}$ levels. Another factor contributing to 

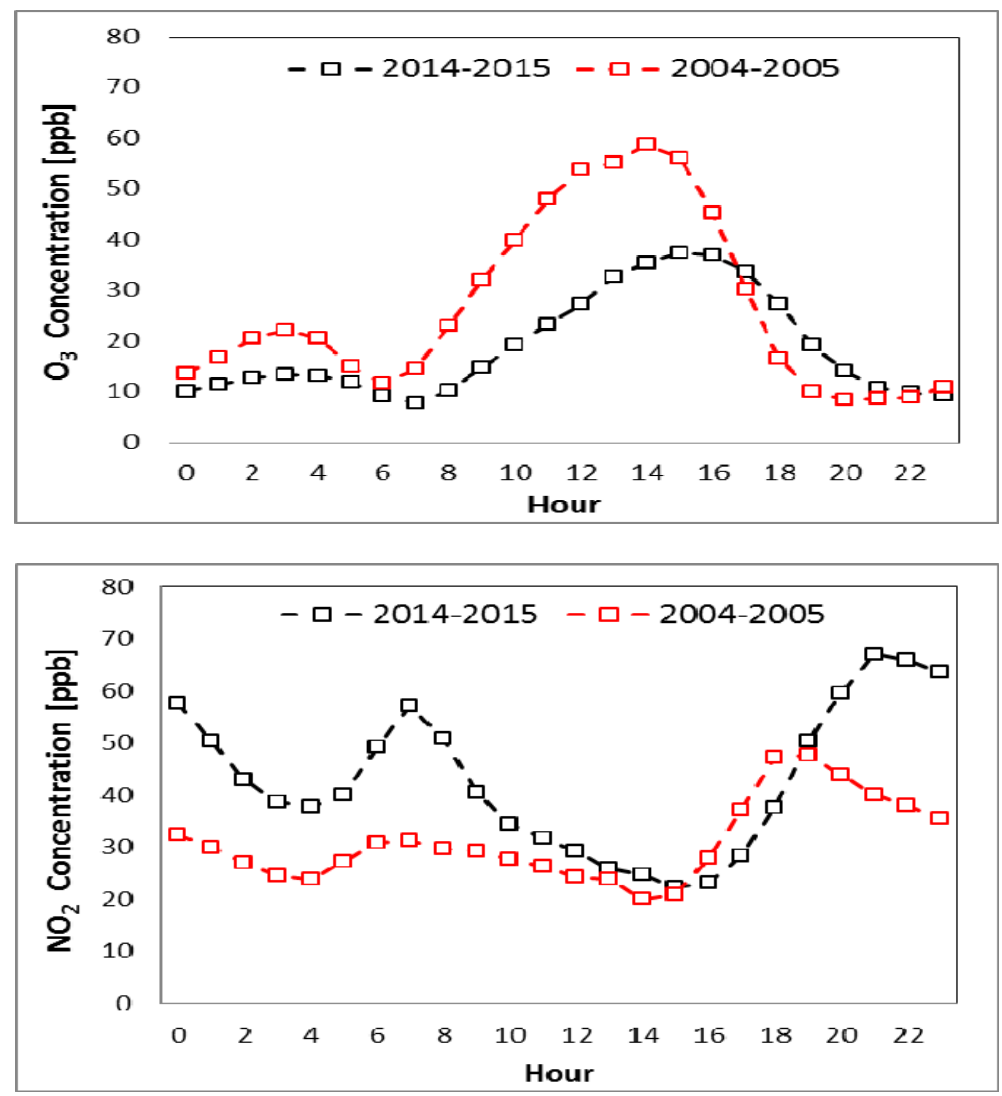

Figure 1: Hourly variations of average concentrations of $\mathrm{O}_{3}$ (top) and $\mathrm{NO}_{2}$ (bottom) in the Fahaheel urban area for the years 2004-2005 and 2014-2015.

this phenomenon is night-time inversion. The dilution processes of nitrogen-based chemicals in the atmosphere are hindered by a lower inversion layer [14]. This layer contains emitted pollutants such as $\mathrm{NO}$ and $\mathrm{NO}_{2}$, which may have caused the hourly concentration of $\mathrm{NO}_{\mathrm{X}}$ to increase during the night [22]. During the daytime, the lower $\mathrm{NO}_{\mathrm{X}}$ levels are mainly due to a higher inversion layer that increases pollutant dilution. In general, the increased rate of $\mathrm{NO}_{2}$ photolysis at midday causes $\mathrm{NO}_{2}$ levels to drop and $\mathrm{O}_{3}$ to rise [23].

The increase in $\mathrm{NO}$ and $\mathrm{NO}_{2}$ levels is associated with a decrease in $\mathrm{O}_{3}$ concentration [24]. NO is a primary pollutant emitted from various sources around the monitoring receptor point. As stated in eqn (4), $\mathrm{NO}$ is converted to $\mathrm{NO}_{2}$ in the reaction with $\mathrm{O}_{3}$. As a result of photolysis, $\mathrm{NO}_{2}$ is reversely produced by stoichiometric balance back to $\mathrm{NO}$ during the day leading to $\mathrm{O}_{3}$ regeneration. Furthermore, the levels of the primary pollutant NO occurred at higher concentrations in 2004-2005 compared to 2014-2015. The same was also detected for $\mathrm{O}_{3}$ ambient concentration. In general, the lower $\mathrm{NO}$ emissions in 2014-2015 are related to the use of catalytic convertors in modern vehicles in addition to lower combustion sources concentration build-up around the vicinity of Fahaheel. 


\subsection{Chemical coupling of $\mathrm{O}_{3}, \mathrm{NO}$ and $\mathrm{NO}_{2}$}

The mixing ratio of $\mathrm{NO}_{2}, \mathrm{O}_{3}$ and the rate of $\mathrm{NO}_{2}$ photolysis $\left(\mathrm{J}_{4}\right)$ was determined to study the photolysis reaction in the atmosphere. It also established the fate of the pollutants in the ambient and their interaction with each other. The average variations of the value of $\mathrm{J}_{4} / \mathrm{k}_{3}$ from eqn (6), was obtained for the study duration and is shown in Fig. 2.

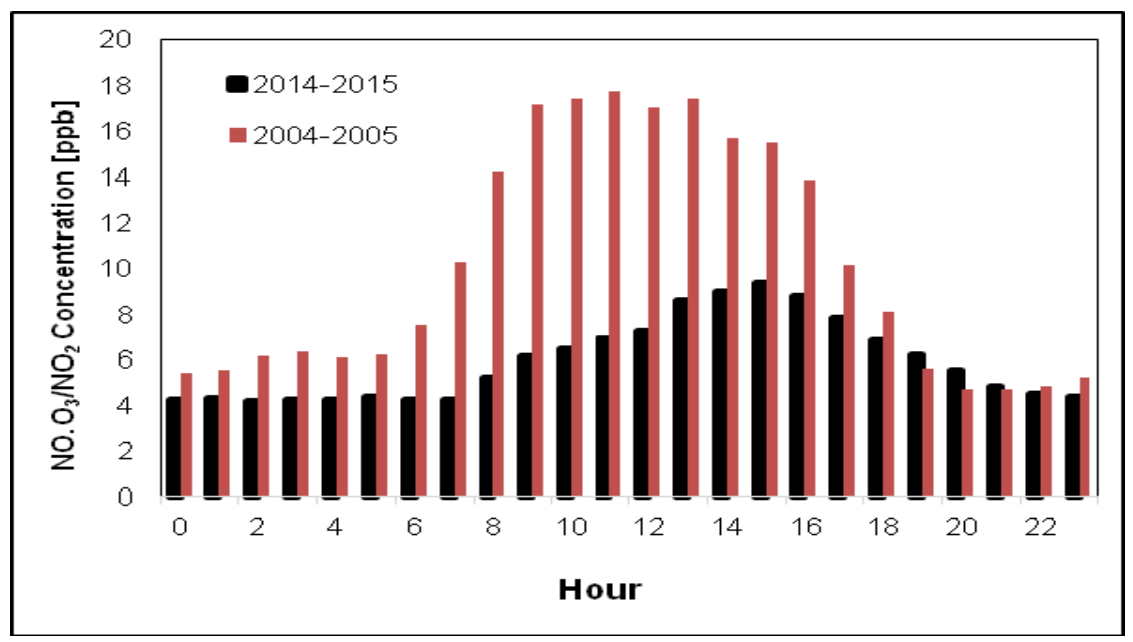

Figure 2: The average variations of $\mathrm{J}_{4} / \mathrm{k}_{3}$ value in 2004-2005 and 2014-2015.

The mean $\mathrm{J}_{4} / \mathrm{k}_{3}$ values varied between 4.71 and $17.74 \mathrm{ppb}$ (2004-2005). The maximum value occurred at 15:00. In addition, the mean values of $\mathrm{J}_{4} / \mathrm{k}_{3}$ varied between 4.18 and 9.38 ppb (2014-2015) with a maximum value also reported at 15:00. Han et al. [17] reported mean $\mathrm{J} / \mathrm{k}$ values ranging from 0.176 to $5.513 \mathrm{ppb}$ in Tianjin, China, and a maximum value at 10:00. Their work provided an adequate description of diurnal averaged variations of $\mathrm{NO}, \mathrm{NO}_{2}$ and $\mathrm{O}_{3}$, consistent with the chemical coupling dominated by the previously described reactions in eqns (4) and (5). This indicates that Fahaheel area is a photocatalytic area which is also consistent with high UV radiation sites (e.g. Kuwait).

\subsection{Diurnal variation of $\mathrm{O}_{\mathrm{X}}$ concentration}

$\mathrm{O}_{\mathrm{X}}$ levels are influenced by photochemical reactions. The variation in the $\mathrm{O}_{\mathrm{X}}$ concentration mean values shows that the concentration of $\mathrm{O}_{\mathrm{X}}$ in 2004-2005 was characterised by a midday peak (Fig. 3). The examined $\mathrm{O}_{\mathrm{X}}$ diurnal variation attributes the behaviour of $\mathrm{O}_{\mathrm{X}}$ to a similar one in the variation of $\mathrm{O}_{3}$. During daytime, the $\mathrm{O}_{\mathrm{X}}$ concentration reached maximum values. Similar results to the $\mathrm{O}_{\mathrm{X}}$ pattern observed in 2004-2005 have been previously reported in many locations including Saudi Arabia and India [4], [20]. However, the diurnal variation of $\mathrm{O}_{\mathrm{X}}$ in the years 2014-2015 did not fit the same pattern as that of 2004-2005. The $\mathrm{NO}_{2} / \mathrm{O}_{\mathrm{X}}$ concentration ratio variation is shown below. $\mathrm{NO}$ is converted to $\mathrm{NO}_{2}$ through an $\mathrm{O}_{3}$ reaction. This is crucial in establishing levels of $\mathrm{NO}_{2}$ and $\mathrm{O}_{3}$. The low ratio of $\mathrm{NO}_{2} / \mathrm{O}_{\mathrm{X}}$ could be attributed to the higher $\mathrm{O}_{3}$ levels during the daytime [13]. This behavioural difference between $\mathrm{NO}_{2}$ and $\mathrm{O}_{3}$ may be related to the time they have to react in the atmosphere or the rate of chemical processes in the studied area. 

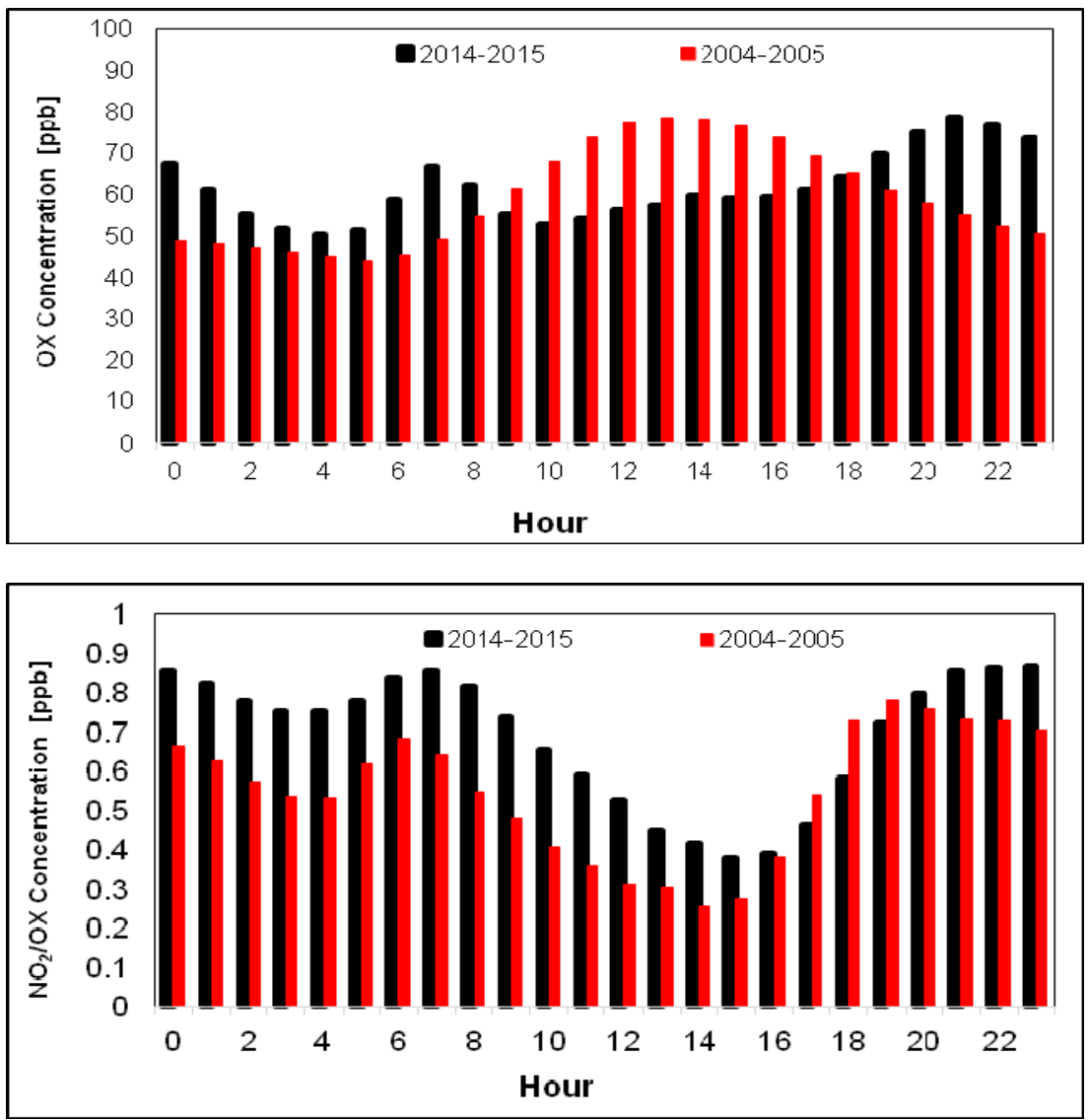

Figure 3: Variations of $\mathrm{O}_{\mathrm{x}}$ (top) mean values and $\mathrm{NO}_{2} / \mathrm{O}_{\mathrm{x}}$ (bottom) mean value ratio in 2004-2005 and 2014-2015.

\subsection{Weekday/weekend differences}

The difference between weekends and weekdays of $\mathrm{O}_{3}$ levels in the Fahaheel area is investigated in this section in order to determine the ozone weekend effect. Differences in ambient air pollutant concentrations such as $\mathrm{NO}_{\mathrm{X}}$ and $\mathrm{O}_{3}$ were extensively studied on weekdays and weekends in urban, suburban and rural sites [25]-[27]. The regional background contributions dominate in sites where concentrations of $\mathrm{O}_{3}$ on weekdays and weekends are approximately equal [4]. On the other hand, differences on weekdays and weekends appear in sites dominated by $\mathrm{O}_{3}$ local production. In general, a valuable indicator of whether $\mathrm{O}_{3}$ originates in local photochemical production or in transportation processes is to study the weekday and weekend differences in $\mathrm{O}_{3}$ and $\mathrm{NO}_{\mathrm{X}}$ levels and NO-titration [4]. The ground concentration of $\mathrm{O}_{3}$ over Fahaheel urban area depends on the photochemical production of $\mathrm{O}_{3}$ in relation to its precursors; $\mathrm{NO}_{\mathrm{X}}$ and VOCs. The weekly traffic patterns are believed to affect the variations of $\mathrm{NO}_{\mathrm{X}}$ and $\mathrm{O}_{3}$ on weekdays and weekends [4]. Vehicle emissions are the main source of $\mathrm{NO}_{\mathrm{X}}$ emissions in the studied urban area; where traffic density on weekends is assumed to be lower than the weekdays due to 
official days-off of work commuters and school/college students. Weekends were on Thursdays and Fridays in Kuwait between 2004-2005, corresponding to Fridays and Saturdays in 2014-2015. Higher $\mathrm{NO}, \mathrm{NO}_{2}$ and $\mathrm{NO}_{\mathrm{X}}$ concentrations and lower $\mathrm{O}_{3}$ concentration on weekdays were observed during daytime in Fahaheel area in 2004-2005 and 2014-2015 as seen in Table 1. The detected trend towards higher levels of $\mathrm{O}_{3}$ concentration and lower $\mathrm{NO}_{\mathrm{X}}$ emissions on weekends supported the ozone weekend effect in Fahaheel urban area. This corresponded to the change in weekends in Kuwait, and complemented the analysis conducted in this study.

Table 1: Weekdays/weekends daytime diurnal variations of $\mathrm{O}_{3}, \mathrm{NO}, \mathrm{NO}_{2}$, and $\mathrm{NO}_{\mathrm{x}}$ (2004-2005) and (2014-2015).

\begin{tabular}{c|c|c|c|c|c}
\hline \multicolumn{2}{c|}{ Daytime } & $\mathrm{O}_{3}(\mathrm{ppb})$ & $\mathrm{NO}(\mathrm{ppb})$ & $\mathrm{NO}_{2}(\mathrm{ppb})$ & \multirow{2}{*}{$\mathrm{NO}_{x}(\mathrm{ppb})$} \\
\hline \multirow{3}{*}{$2004-2005$} & Weekdays & 42.29 & 12.64 & 31.10 & 43.83 \\
\cline { 2 - 6 } & Weekends & 47.67 & 10.02 & 27.74 & 37.88 \\
\cline { 2 - 6 } & All & 43.85 & 11.878 & 30.13 & 42.10 \\
\hline \multirow{3}{*}{$2014-2015$} & Weekdays & 28.23 & 9.76 & 37.02 & 47.27 \\
\cline { 2 - 6 } & Weekends & 31.35 & 7.45 & 30.73 & 38.71 \\
\cline { 2 - 6 } & All & 29.12 & 9.12 & 35.28 & 44.09 \\
\hline
\end{tabular}

\section{CONCLUSION}

Examining the variations in $\mathrm{O}_{3}$ and $\mathrm{NO}_{\mathrm{X}}$ in the urban area of Fahaheel (Kuwait) over the years (2004-2005) and (2014-2015) resulted in determining their atmospheric behaviour. $\mathrm{O}_{3}$ levels were clearly more elevated in the summer months. They were seen to gradually increase until reaching the month of July in 2004-2005 and the month of August in 2014-2015. The patterns of hourly diurnal variation of $\mathrm{O}_{3}$ and $\mathrm{NO}_{\mathrm{X}}$ varied between weekdays and weekends. It was observed that $\mathrm{O}_{3}$ reached higher overall weekdays and weekends concentrations in 2004-2005 compared to 2014-2015. In addition, higher NO, $\mathrm{NO}_{2}$ and $\mathrm{NO}_{\mathrm{X}}$ concentrations and lower $\mathrm{O}_{3}$ concentration on weekdays were observed during daytime in Fahaheel area in 2004-2005 and 2014-2015. The detected trend towards higher levels of $\mathrm{O}_{3}$ concentration and lower $\mathrm{NO}_{\mathrm{X}}$ emissions on weekends supported the ozone weekend effect Fahaheel urban area. Furthermore, the levels of the primary pollutant NO occurred at higher concentrations in 2004-2005 compared to 2014-2015. This is related to the use of catalytic convertors in modern vehicles as well lower combustion sources concentration build-up around the vicinity of Fahaheel. The present study provided insight into ground level ozone variations in urban Fahaheel, yet the interpretation was limited by meteorological and VOCs data inadequacies. Future studies need to explore more detailed relationships between $\mathrm{NO}_{\mathrm{x}}, \mathrm{VOCs}$, and $\mathrm{O}_{3}$ in the Fahaheel area.

\section{ACKNOWLEDGEMENTS}

This study was funded by Kuwait Scientific Research Centre (KISR) in support to Project EM070G. The authors wish to express their gratitude to the Air Pollution Monitoring Division, Environment Public Authority, Kuwait (KEPA) for providing air quality data and to the Kuwait Foundation for the Advancement of Sciences (KFAS) for funding the scientific mission. 


\section{REFERENCES}

[1] Adame, J.A., Notario, A., Villanueva, F. \& Albaladejo, J., Application of cluster analysis to surface ozone, $\mathrm{NO}_{2}$ and $\mathrm{SO}_{2}$ daily patterns in an industrial area in Central-Southern pain measured with a DOAS system. The Science of the Total Environment, 429, pp. 281-291, 2012.

[2] Tiwari, S., Dahiya, A. \& Kumar, N., Investigation into relationships among NO, $\mathrm{NO}_{2}, \mathrm{NOx}, \mathrm{O}_{3}$, and $\mathrm{CO}$ at an urban background site in Delhi, India. Atmospheric Research, 157, 119-126, 2015.

[3] Mazzeo, N.A., Venegas, L.E. \& Choren, H., Analysis of $\mathrm{NO}, \mathrm{NO}_{2}, \mathrm{O}_{3}$ and $\mathrm{NO}_{\mathrm{X}}$ concentrations measured at a green area of Buenos Aires City during wintertime. Atmospheric Environment, 39(17), pp. 3055-3068, 2005.

[4] Alghamdi, M.A. et al., Temporal variations of $\mathrm{O}_{3}$ and NOx in the urban background atmosphere of the coastal city Jeddah, Saudi Arabia. Atmospheric Environment, 94, pp. 205-214, 2014.

[5] Cleveland, W.S., Graedel, T.E., Kleiner, B. \& Warner, J.L., Sunday and Workday Variations in Photochemical Air Pollutants in New Jersey and New York. Science, 186(4168), pp. 1037-1038, 1974.

[6] Fujita, E.M. et al., Diurnal and weekday variations in the source contributions of ozone precursors in California's South Coast Air Basin. Journal of the Air \& Waste Management Association, 53(7), pp. 844-863, 2003.

[7] Jimenez, P., Parra, R., Gasso, S. \& Baldasano, J.M., Modeling the ozone weekend effect in very complex terrains: a case study in the North eastern Iberian Peninsula. Atmospheric Environment, 39(3), pp. 429-444, 2005.

[8] Traub., M. \& Lelieveld, J., Cross-tropopause transport over the eastern Mediterranean. Journal of Geophysical Research Atmosphere, 108(D23), pp. 4712, 2003.

[9] Lelieveld, J. et al., Severe ozone air pollution in the Persian Gulf region. Atmospheric Chemistry and Physics, 9, 1393-1406, 2009.

[10] Mazzuca, G.M. et al., Ozone Production and Its Sensitivity to NOx and VOCs: Results 1 from the DISCOVER-AQ, Atmospheric Chemistry and Physics, 16, 14463-14474, 2016.

[11] Sharma, A., Sharma, S.K., Rohtash \& Mandal T.K., Influence of ozone precursors and particulate matter on the variation of surface ozone at an urban site of Delhi, India. Sustainable Environment Research, 26(2), pp. 76-83, 2016.

[12] Kumar, A., Singh, D., Anandam, K., Kumar, K. \& Jain, V.K., Dynamic interaction of trace gases (VOCs, Ozone, and NOx) in the rural atmosphere of sub-tropical India. Air Quality, Atmosphere \& Health, 10(7), pp. 885-896, 2017.

[13] Pancholi, P., Kumar, A., Bikundia, D.S. \& Chourasiya, S., An observation of seasonal and diurnal behavior of O3-NOx relationships and local/regional oxidant $\left(\mathrm{O}_{\mathrm{X}}=\mathrm{O}_{3}+\mathrm{NO}_{2}\right)$ levels at a semi-arid urban site of western India. Sustainable Environment Research, 28(2), pp. 79-89, 2018.

[14] Al-Salem, S.M. \& Khan, A.R., Comparative assessment of ambient air quality in two urban areas adjacent to petroleum downstream/upstream facilities in Kuwait. Brazilian Journal of Chemical Engineering, 25(4), pp. 683-696, 2008.

[15] Song, F., Shin, J.Y., Jusino-Atresino, R. \& Gao, Y., Relationships among the springtime ground-level $\mathrm{NOx}, \mathrm{O}_{3}$ and $\mathrm{NO}_{3}$ in the vicinity of highways in the US East Coast. Atmospheric Pollution Research, 2(3), pp. 374-83, 2011. 
[16] Al-Salem, S.M. \& Khan, A.R., Monitoring and modelling the trends of primary and secondary air pollution precursors: The case of the state of Kuwait, International Journal of Chemical Engineering, 2010, pp. 1-12, 2010.

[17] Han, S. et al., Analysis of the Relationship between $\mathrm{O}_{3}, \mathrm{NO}$ and $\mathrm{NO}_{2}$ in Tianjin, China, Aerosol and Air Quality Research. 11, pp. 128-139, 2011.

[18] Li, K. et al., Smog chamber study on aging of combustion soot in isoprene $/ \mathrm{SO}_{2} / \mathrm{NOx}$ system: Changes of mass, size, effective density, morphology and mixing state. Atmospheric Research, 184, 139-148, 2017.

[19] Duenas, C., Fernandez, M.C., Canete, S., Carretero, J. \& Liger, E., Analyses of ozone in urban and rural sites in Malaga (Spain). Chemosphere, 56(6), pp. 631-639, 2004.

[20] Pires, J.C.M., Alvim-Ferraz, M.C.M. \& Martins, F.G., Surface ozone behaviour at rural sites in Portugal. Atmospheric Research, 104-105, pp. 164-171, 2012.

[21] Wang, Y.H., Hu, B., Tang, G.Q., Ji, D.S., Zhang, H.X. \& Bai, J.H., Characteristics of ozone and its precursors in Northern China: a comparative study of three sites. Atmospheric Research, 132, pp. 450-459, 2013.

[22] Yadav, R., Sahu, L.K., Jaaffrey, S.N.A. \& Beig, G., Distributions of ozone and related trace gases at an urban site in western India. Journal Atmospheric Chemistry, 71(2), pp. 125-144, 2014.

[23] Ismail, M., Abdullah, S., Yuen, F.-S., \& Ghazali, N.A., A ten-year investigation on ozone and it precursors at Kemaman, Terengganu, Malaysia. Environment Asia, 9(1), pp. 1-8, 2016

[24] Ramli, N.A., Ghazali, N.A. \& Yahaya, A.S., Diurnal fluctuations of ozone concentrations and its precursors and prediction of ozone using multiple linear regressions. Malaysian Journal of Environmental Management, 11(2), pp. 57-69, 2010.

[25] Shutters, S.T. \& Balling, R.C., Weekly periodicity of environmental variables in Phoenix. Arizona. Atmospheric Environment, 40(2), pp. 304-310, 2006.

[26] Stephens, S. et al., Weekly patterns of Mexico City's surface concentrations of CO, NOx, PM10 and O3 during 1986-2007. Atmospheric Chemistry and Physics, 8, pp. 5313-5325, 2008.

[27] Semple, D.R., Song, F. \& Gao, Y., Seasonal characteristics of ambient nitrogen oxides and ground-level ozone in metropolitan North eastern New Jersey, Atmospheric Pollution Research, 3(2), 247-257, 2012. 